\title{
A study to determine causes, prevalence and knowledge regarding consequences of substance abuse: a community based cross sectional study
}

\author{
Shridevi Kotina ${ }^{1}$, Gokuldas V. Sawant ${ }^{1}$, Prashant R. Kokiwar ${ }^{2} *$ \\ ${ }^{1}$ Associate Professor, ${ }^{2}$ Professor \& HOD, Department of Community Medicine, Malla Reddy Institute of Medical
} Sciences, Hyderabad, Telangana, India

Received: 19 January 2016

Accepted: 19 February 2016

*Correspondence:

Dr. Prashant R. Kokiwar,

E-mail: kokiwar@gmail.com

Copyright: (C) the author(s), publisher and licensee Medip Academy. This is an open-access article distributed under the terms of the Creative Commons Attribution Non-Commercial License, which permits unrestricted non-commercial

\section{ABSTRACT}

Background: Current tobacco use in any form is $34.6 \%$ of adults and in males it is $47.9 \%$ and the prevalence of tobacco smokers is $14 \%$ in adults with $24.3 \%$ in Males. 8 Use of smokeless tobacco was found to be $24.3 \%$ in males. The objectives of the study were to determine causes, prevalence and knowledge regarding consequences of substance abuse.

Methods: A community based cross sectional study was carried out. Data was recorded in a predesigned and pretested questionnaire as well as physical health consequences were enquired about. Only Men between 10-19 years were selected by house to house survey, and were explained about the protocol and purpose of the study. They were interviewed by interacting in local language.

Results: Majority belonged to 13-15 years. Majority of the respondents were unskilled employees (39.76). Majority of the respondents have completed secondary education. Among the respondents, majority belonged to upper middle class. Majority of the respondents belong to nuclear families. Major cause of initiation of substance abuse was Peer Pressure (52\%), followed by feel of experimenting (20\%). Overall 84\% (206/244) were having knowledge regarding harmfulness of substance abuse.

Conclusions: Prevalence of substance abuse was found to be $66 \%$. Majority that is $48.54 \%$ were consuming alcohol and $23.36 \%$ were smoking. Maximum that is $84 \%$ were having knowledge regarding harmfulness of substance abuse. Majority of skilled workers $(67 \%)$ were addicted. Majority that is $87.66 \%$ of illiterates were addicted. $52 \%$ of subjects have started addiction due to peer pressure and $41 \%$ started only by experimenting.

Keywords: Substance use, Peer pressure, Alcohol, Smoking

\section{INTRODUCTION}

Substance is defined as "Any substance that, when taken in to the living organism, may modify one or more of its functions". ${ }^{1}$ Drug abuse is defined as self-administration of drugs for non-medical reasons, in quantities and frequencies which may impair an individual's ability to function effectively and which may result in social, physical and emotional harm. ${ }^{1}$
Most commonly used substances in Indian communities are - tobacco - smoking/smoke less, alcohol, toddy, gutkha, paan, cigarettes. ${ }^{1}$

About 230 million people or 5 percent of the world's adult population are estimated to have used an illegal drug use at least once in $2010 .^{2}$ Alcohol and other drug users number about 27 million, which is $0.6 \%$ of the world's adult population. ${ }^{2}$ Alcohol and other drug use determine economic and social development and contribute to crime, instability, insecurity and they also 
cause major burden to society causing economic cost, health cost, crime related cost and losses in Productivity. ${ }^{3}$

In the world, prevalence was found to be $38.3 \% .{ }^{4}$ In India Kerala stands first followed by Maharashtra, Punjab, and Andhra Pradesh.4

In 2012, about 3.3 million deaths, or $5.9 \%$ of all global deaths, were attributable to alcohol consumption. Alcohol alone kills 0.2 million people each year. ${ }^{5}$ Alcohol consumption also contributes to about 10 percent of the disease burden due to tuberculosis, epilepsy, hemorrhagic stroke and hypertensive heart disease in the world. ${ }^{4}$

India ranks $4^{\text {th }}$ in the total tobacco consumption in the world. Chewing tobacco has been a tradition in India for centuries. Of the total amount of tobacco produced in the country, around $48 \%$ is in the form of chewing tobacco, $38 \%$ as bidis, and only $14 \%$ as cigarettes. Thus, bidis, snuff and chewing tobacco (such as gutka, khaini and zarda) form the bulk (86\%) of India's total tobacco production. ${ }^{5}$ Most people consume tobacco in the form of non-cigarette items such as hand-rolled bidis, chewing etc. $^{6}$

The World Health Organization predicts that tobacco deaths in India may exceed 1.5 million annually by 2020 . WHO estimated a prevalence of tobacco consumption of all forms were $65 \%$ among men, based on small scale studies conducted in the past. ${ }^{7}$

Current tobacco use in any form is $34.6 \%$ of adults and in males it is $47.9 \%$ and the prevalence of tobacco smokers is $14 \%$ in adults with $24.3 \%$ in males. ${ }^{8}$ Use of smokeless tobacco was found to be $24.3 \%$ in males. ${ }^{8}$

$59 \%$ of the Indian population abuse toddy. $40.8 \%$ people are multiple drinkers in addition to toddy, among which $49.2 \%$ are of 13-20 years age group. In Telangana dependence was seen in $4.1 \%$ and suffering was in $1 \%$ population. ${ }^{9}$

Present study was undertaken to study the prevalence of different types of substance abuse, to know the causes of substance abuse, to know the consequences of substance abuse, to compare the knowledge regarding the consequences of substance abuse.

\section{METHODS}

Present study is a Community based cross sectional study was carried out in the Medicine department of Malla Reddy hospital with 244 study population.

Sample size calculation- $\mathrm{N}=4 \mathrm{pq} / \mathrm{L}^{2}$.

Prevalence of substance abuse was taken as 32.7 and with allowable error of $19 \%$ and confidence interval of $95 \%$, the calculated sample size is 228 , a non response rate of $6 \%$ was added giving the sample size of $244 .^{10}$

\section{Data collection tool}

- A Predesigned and pretested questionnaire which include Identification data; Socio demographic profile; Practice of substance abuse; Causes of substance abuse; Causes of initiation of substance abuse $^{1,9}$

Psychological issues, medical issues, substance abuse as coping mechanisms, family factors, alcohol and family celebrations, Social and environmental factors relationship issues, abuse, peer pressure, experimenting, life stresses, media influence trauma, academic failure.

\section{Knowledge regarding consequences of substance abuse $^{1,11}$}

To know the consequences of substance abuse, the proforma was divided in to Physical Health Consequences, Mental Health Consequences and Social Impact and the data was collected based on the questions in the proforma as follows

\section{Physical health consequences enquired about:}

- $\quad$ Lungs - Lung cancer, chronic obstructive pulmonary disease, Increased severity Asthma, Increased risk of developing various respiratory infections,

- Heart - Coronary heart disease, Angina pectoris, Heart attack, Increased risk of repeat heart attack, arrhythmia, aortic aneurism cardiomyopathy.

- Blood vessels - Peripheral vascular disease, Thromboanginitis obliterans

- Skin- Early wrinkling, Finger nail discoloration, psoriasis, palmoplantar pustulosis

- Cancer- Lung cancer, oral cancer, Bladder cancer, Cervical etc.

- Bones - Osteoporosis, osteoarthritis, delayed fracture healing.

- Reproduction- Miscarriage, Infertility, Impotence.

- Brain - TIA, Stroke, sclerosis.

- Mental health consequences ${ }^{11}$

- Alcohol dependence syndrome, Suicidal ideation, Depression, Anxiety, Decrease in academics.

- Social Impact ${ }^{11}$

- Unemployment, Physical violence, Domestic violence, reduced economy.

Inclusion criteria: Adult men between 10-19 years

Data was collected by house to house survey. Only Men between 10-19 years were selected by house to house survey, and were explained about the protocol and purpose of the study. They were interviewed by interacting in local language.

After interview, the doubts of the participants were cleared and imparted correct knowledge regarding harmfulness and consequences of substance abuse. 
The filled questionnaire with ticked answers were collected and then the collected data was entered on Microsoft excel.

After estimating the prevalence of substance abuse, the data was divided in to two groups, one group with addiction of substance abuse and the other without addiction.

Then the two groups were compared and analysed with respect to socio demographic profile, Knowledge regarding causes and consequences.

\section{RESULTS}

Table 1: Age wise distribution of the respondents.

\begin{tabular}{|lll|}
\hline Age & $\begin{array}{l}\text { Substance abuse } \\
\text { Yes } \\
\text { Frequency (\%) }\end{array}$ & $\begin{array}{l}\text { Substance abuse } \\
\text { No }\end{array}$ \\
\hline $10-12$ & $45(27.78)$ & Frequency $(\%)$ \\
\hline $13-15$ & $54(33.34)$ & $31(37.80)$ \\
\hline $16-17$ & $34(21)$ & $11(13.42)$ \\
\hline $18-19$ & $29(17.9)$ & $10(12.2)$ \\
\hline Total & $162(100)$ & $82(100)$ \\
\hline
\end{tabular}

Table 2: Distribution of respondents according to occupation.

\begin{tabular}{|llll|}
\hline Occupation & $\begin{array}{c}\text { Addiction } \\
\text { No. }(\%)\end{array}$ & $\begin{array}{l}\text { No addiction } \\
\text { No. }(\%)\end{array}$ & $\begin{array}{l}\text { Total } \\
\text { No. }(\%)\end{array}$ \\
\hline Professionals & $14(56)$ & $11(44)$ & $25(10.24)$ \\
\hline Skilled & $65(53)$ & $32(47)$ & $34(13.94)$ \\
\hline Unskilled & $53(67)$ & $14(33)$ & $97(39.76)$ \\
\hline Unemployed & $5(79)$ & $3(21)$ & $67(27.45)$ \\
\hline Business & $18(62)$ & $16(38)$ & $8(3.28)$ \\
\hline Students & $7(53)$ & $6(47)$ & $13(5.33)$ \\
\hline Total & 162 & 82 & $244(100)$ \\
\hline
\end{tabular}

Chi square $=0.081 ; \mathrm{P}>0.05 ;$ Not significant

$66 \%(162 / 244)$ of the subjects were having the habit of taking some or the other type of substance abuse. Majority that is $46 \%(112 / 162)$ were taking, more than one type of substance abuse.

Different types of use of substance abuse were Alcohol (48.54\%), Cigarette smoking (23.36\%), Tobacco $(8.76 \%)$, Pan (3.65\%), Toddy (6.93\%), Guthka (6.93\%), and Khaini $(2.2 \%)$ respectively.

Majority belonged to 13-15 years, followed by 10-12 years age group.

Majority of the respondents were unskilled employees (39.76), and then followed by Unemployed (27.45), Skilled, Professionals, Students and Business. Occupation of the respondents is not significantly different in both the groups (Table 2).
Table 3: Education among the respondents.

\begin{tabular}{|lcc|l|}
\hline Education & Addiction & $\begin{array}{l}\text { No } \\
\text { addiction }\end{array}$ & Total \\
\hline Primary & 13 & 10 & $23(9.43)$ \\
\hline Secondary & 44 & 31 & $75(30.74)$ \\
\hline Intermediate & 20 & 11 & $31(12.71)$ \\
\hline Illiterate & 52 & 8 & $60(24.6)$ \\
\hline Graduation & 33 & 21 & $54(22.13)$ \\
\hline Total & 162 & 82 & $244(100)$ \\
\hline
\end{tabular}

CHI square $=14.84 ; \mathrm{p}<0.05$; highly significant

Majority of the respondents have completed secondary education, followed by illiterates and then Graduates. Education of the respondents who are not having substance abuse is significantly better than the persons who are taking substance abuse.

Table 4: Socio economic status according to B. G. Prasad classification.

\begin{tabular}{|llll|}
\hline Income & $\begin{array}{l}\text { Substance use } \\
\text { Yes }\end{array}$ & $\begin{array}{l}\text { Substance use } \\
\text { No }\end{array}$ & Total \\
\hline $\begin{array}{l}\text { Upper } \\
\text { class }\end{array}$ & 35 & 26 & $61(25 \%)$ \\
\hline $\begin{array}{l}\text { Upper } \\
\text { middle } \\
\text { class }\end{array}$ & 49 & 28 & $77(31.55)$ \\
\hline $\begin{array}{l}\text { Middle } \\
\text { class }\end{array}$ & 35 & 17 & $52(21.32)$ \\
\hline $\begin{array}{l}\text { Lower } \\
\text { middle } \\
\text { class }\end{array}$ & 36 & 11 & $47(19.26)$ \\
\hline $\begin{array}{l}\text { Lower } \\
\text { class }\end{array}$ & 7 & 0 & $7(2.87)$ \\
\hline Total & 162 & 82 & $244(100)$ \\
\hline
\end{tabular}

Among our respondents, majority belonged to upper middle class, followed by upper class and then middle class. Socio economic status of the respondents is not significantly different in both the groups.

Majority of the respondents belong to nuclear families, and $80.24 \%$ of the respondents in nuclear families have habit of substance abuse and habit of substance abuse is significant more in nuclear families compared to joint family (Table 5).

Major cause of initiation of substance abuse was peer pressure $(52 \%)$, next followed by feel of experimenting $(20 \%)$, then media influence and life stress $(5 \%)$.

Overall 84\% (206/244) were having knowledge regarding harmfulness of substance abuse, $80.24 \%$ (130/162) of those who have the habit of substance abuse and $92.7 \%$ $(76 / 82)$ of those who were not having habit are having the knowledge. 
Table 5: Distribution of respondents according to type of family.

\begin{tabular}{|llll|}
\hline Type of family & $\begin{array}{l}\text { Substance } \\
\text { Use } \\
\text { Yes }\end{array}$ & $\begin{array}{l}\text { Substance } \\
\text { Use } \\
\text { No }\end{array}$ & Total \\
\hline Nuclear & $130(80.24)$ & $32(19.75)$ & $162(66.4)$ \\
\hline Joint & $28(36.37)$ & $49(63.63)$ & $77(32)$ \\
\hline Extended nuclear & $4(80)$ & $1(20)$ & $5(2)$ \\
\hline Total & 162 & 82 & $244(100)$ \\
\hline
\end{tabular}

Chi square $=45.47 ; \mathrm{P}<0.05 ;$ highly significant

Table 6: Cause of initiation of substance abuse among those who are using substance.

\begin{tabular}{|lll|}
\hline \multirow{2}{*}{ Cause for initiation } & \multicolumn{2}{c|}{ Substance Use } \\
\hline Family problems & Frequency & $\%$ \\
\hline Peer pressure & 17 & 8 \\
\hline Trauma & 109 & 52 \\
\hline Media influence & 13 & 6 \\
\hline Experimenting & 11 & 5 \\
\hline Academic failure & 41 & 20 \\
\hline Love failure & 3 & 1.5 \\
\hline Ancestors & 3 & 1.5 \\
\hline Life stress & 1 & 1 \\
\hline Total & 11 & 5 \\
\hline
\end{tabular}

Table 7: Knowledge regarding health Problems due to substance abuse.

\begin{tabular}{|lll|}
\hline Heart & $\begin{array}{c}\text { Substance use } \\
\text { Yes }(\%)\end{array}$ & $\begin{array}{l}\text { Substance use } \\
\text { No }(\%)\end{array}$ \\
\hline Skin & $44(27.16)$ & $36(43.9)$ \\
\hline Lung & $2(1.23)$ & $4(4.88)$ \\
\hline Cancer & $73(45.06)$ & $54(65.86)$ \\
\hline Bones & $80(49.38)$ & $49(59.76)$ \\
\hline Liver & $14(8.64)$ & $9(10.98)$ \\
\hline Kidney & $73(45.06)$ & $44(53.66)$ \\
\hline Reproduction & $39(24.07)$ & $22(26.83)$ \\
\hline Brain & $7(4.32)$ & $7(8.53)$ \\
\hline Others & $4(2.47)$ & $4(4.88)$ \\
\hline Total & $12(7.41)$ & $6(7.32)$ \\
\hline
\end{tabular}

*cataract, Macular degeneration, Snoring, Periodontal diseases, stomach and duodenal ulcers, Crohns disease, impaired immunity; Chi square=5.059; $\mathrm{P}<0.05$; Not significant

There is no significant difference in knowledge regarding consequences of substance abuse between those who are taking substance and those who are not taking substance.

$47 \%$ of the respondents with substance abuse and $95.12 \%$ without substance abuse knew that there will be mental health problems on intake of substance abuse and the difference is highly significant (Chi square-53.216, $\mathrm{P}$ $<0.05)$.
$85.8 \%$ of the respondents with substance abuse and $28.05 \%$ of the respondents without substance abuse has knowledge that there will be social problems with substance abuse is and the difference is highly significant (Chi square- 103.41, P <0.005).

\section{DISCUSSION}

The overall prevalence of substance abuse among urban health centre field practice area was found to be $66 \%$. The prevalence was lesser than the prevalence found in Bhubaneswar (74.03\%) and higher than that found in Karimnagar district $(32.7 \%)$ by Kokiwar PR et al and AA Malik et al $(35.4 \%)$ in Bari Iman. ${ }^{11-13}$

Alcohol intake was high showing prevalence of $48.54 \%$, followed by cigarette smoking $(23.36 \%)$, then tobacco $(8.76 \%)$, Pan $(3.65 \%)$, Toddy (6.93\%), Guthka (6.93\%), Khaini (2.2\%) respectively where as in a study in Mumbai by Din Prakash Ranjan et al, smokeless tobacco $(43.7 \%)$ intake was more prevalent, then followed by smoking tobacco $(21 \%)$, followed by Alcohol (12.2\%). ${ }^{14}$ In another study by GK Padhy et al, cigarette smoking was found to be most common type of substance abuse (72.84\%), followed by Alcohol (68.25\%), Guthka $(24.58 \%)$ and others. ${ }^{12}$

Alcohol intake in our study is quite high, might be because of lack of knowledge regarding consequences, easy availability and accessibility.

Only $6.93 \%$ of substance abusers took Guthka which is quite less compared to the study of D N Sinha and P C Gupta where prevalence was reported to be $43 \% .^{15}$

Prevalence rate of substance abuse is more in the age group of $13-15$ years, (33.34\%), followed by $27.78 \%$ at 10-12 years of age, then followed by $16-17$ years $(21 \%)$. In the study conducted by GK Padhey et al in medical college students the Prevalence was more in the age group of 17-19 years (44.47\%), followed by 15-18 yrs $(38 \%){ }^{12}$ Occupation was not associated with prevalence of substance abuse, showing that occupation does not contribute to substance abuse similar to Kokiwar PR et al study. $^{10}$

There is significant association between substance abuse and education with $\mathrm{P}<0.05$ which is similar to Kokiwar PR et al study. ${ }^{10}$

There was no significant association between social class and substance abuse in the study, similar findings was reported by Kokiwar et al, Kohler et al. ${ }^{10,16}$ However Neufeld et al observed that prevalence of substance abuse was more common in lower class. ${ }^{17}$

Major cause of initiation of substance abuse was Peer Pressure $(52 \%)$, next followed by feel of experimenting $(20 \%)$, then media influence and life stress (5\%), and then followed by academic failure, love failure, ancestors etc.

Similar to our findings Peer pressure $(52.9 \%)$ was major reason, then followed by enjoyment $(21.1 \%)$ in Kokiwar 
PR et al, where as in a study done by GK Padhey et al academic pressure (69\%) was reported as the major cause. $^{10,12}$ The difference in cause may be due to different study settings and environment.

Regarding knowledge on consequences of substance abuse $45.06 \%$ knew liver will be affected due to substance abuse compared to $62.5 \%$ in Dhaka by a study done by Zaman MS et al, 45.06\% knew that lung will be affected in the study compared to only few that is $3.3 \%$ in Dhaka, Only $2.47 \%$ in the present study knew that Brain will be affected where as $34.2 \%$ of respondents in Dhaka knew that Brain will be affected. ${ }^{18}$ In the present study $27.16 \%$ knew that heart will be affected due to intake of substances and only $17.5 \%$ in Dhaka study. ${ }^{18}$

In the present study $85.8 \%$ knew that social problems occur after substance abuse where as in a study done in Dhaka around $13.3 \%-52.5 \%$ knew that there are social consequences after intake of substance abuse. ${ }^{18} 47 \%$ in the present study knew that there will be Mental health consequences after substance abuse similar to Zaman MS et al study where $7.5 \%-55.8 \%$ had knowledge. ${ }^{18}$

\section{CONCLUSION}

Prevalence of substance abuse was found to be $66 \%$. Majority that is $48.54 \%$ were consuming alcohol and $23.36 \%$ were smoking. Maximum that is $84 \%$ were having knowledge regarding harmfulness of substance abuse. Majority of skilled workers $(67 \%)$ were addicted. Majority that is $87.66 \%$ of Illiterates were addicted. $52 \%$ of subjects have started Addiction due to peer pressure and $41 \%$ started only by experimenting.

\section{Funding: No funding sources}

Conflict of interest: None declared

Ethical approval: The study was approved by the Institutional Ethics Committee

\section{REFERENCES}

1. Park K. Mental Health. In: Park K, editor. Park's Text Book of Preventive and Social medicine, $22^{\text {nd }}$ ed. Jabalpur: Banarsidas Bhanot Publishers. 2013:782-96.

2. UNODC, "World drug report" United Nations publication, New York. 2014:11-25.

3. Deressa W, Azazh A. Substance use and its predictors among undergraduate medical students of Addis Ababa university in Ethiopia. BMC Public Health. 2011;11:article 660.

4. Alcohol consumption in India on the rise: WHO report. Available from: http://www.midday.com/articles/alcohol-consumption-in-india-onthe-rise-who-report/15299173.

5. WDR. World drug report. United Nations Office on Drugs and Crime, Vienna. 2012:10-8.

6. Rani M, Bonu S, Jha P, Nguyen SN, Jamjoum L. Tobacco use in India: prevalence and predictors of smoking and chewing in national cross sectional household survey. Tob Control 2003;12:e4. http://tobaccocontrol.bmj.com/content/12/4/e4.full.ht $\mathrm{ml}$.

7. Global Adult Tobacco Survey (GATS) - India Fact Sheet-2009-2010. Available from: ccd.cdc.gov/gtssdata/Ancillary/DownloadAttachment .aspx?ID=964.

8. Tobacco use in India. Available from: http://www.who.int/tobacco/surveillance/en_tfi_india _gats_fact_sheet.pdf.

9. http://www.niir.org/projects/projects/tobacco-panmasala-khaini-gutkha-supari-zarda-mouth-freshenerkimam-cigarettes/z,,49,0,64/index.html.

10. Kokiwar PR, Jogdand GS. Prevalence of substance use among male adolescents in an urban slum area of Karimnagar district, AndhraPradesh. Indian J Public Health. 2011;55:42-5.

11. Assessment of Causes, Prevalence and Consequences of Alcohol and Drug Abuse among Mekelle University, CSSL $2^{\text {nd }}$ Year Students, wosen Keskis. Department of Psychology, Mekelle university, Meelle university, Mekelle, Ethiopia.

12. Padhy GK, Das S, Sahu T, Parida S. Prevalence and causes of substance abuse among undergraduate medical college students. Indian Medical Gazatte. 2014;276-82.

13. Malik AA, Nawaz S, Tahir AA, Ahmed S, Hanif N, Aslam $\mathrm{J}$ et al. Knowledge and awareness of harmful effect of substance abuse among users and non-users: a cross sectional study. J Pak Med Assoc. 2012;62(4):412-5.

14. Ranjan DP, Namita RM, Chaturvedi A. Study of Prevalence Of Drug Abuse in Aged 15 Years \& above in the Urban Slum Community of Mumbai. Indian J Prev Soc Med. 2012;41:117-26.

15. Sinha DN, Gupta PC. Tobacco use among school personnel in Orissa. Indian $\mathbf{J}$ Public Health. 2004;48(3):123-5.

16. Kohler S, Richter A, Lampert T, Mensink GB. Alcohol consumption among adolescents in Germany: Results of EsKiMo. Bundesgesundheitsblatt Gegundheitsforschung Gesundheitsschutz 2009;52:745-52.

17. Neufeld KJ, Peters DH, Rani M, Bonu S, Brooner RK. Regular use of alcohol and tobacco in India and its association with age, gender, and poverty. Drug Alcohol Depend. 2005;77:283-91.

18. Zaman MS, Almajidi WA, Hurunaher. Knowledge on the effects of drug abuse among the students in a selected high school in Dhaka City. Bangladesh J Dental Res edu. 2013;3:12-8.

Cite this article as: Kotina S, Sawant GV, Kokiwar PR. A study to determine causes, prevalence and knowledge regarding consequences of substance abuse: a community based cross sectional study. Int $\mathbf{J}$ Community Med Public Health 2016;3:730-4. 